\title{
ANALISIS KADAR AFLATOKSIN JAGUNG LOKAL TIMOR PADA PERLAKUAN LAMA PENGERINGAN MENGGUNAKAN UDARA ALAMIAH
}

\section{ANALISIS FOR AFLATOXIN CONTENT OF TIMOR LOCAL CORN DUE TO DRYING PERIOD USING NATURAL AIR STREAM}

\author{
Jefrianus Nino ${ }^{1 凶}$, Eduardus Y. Neonbeni ${ }^{1}$ \\ ${ }^{1}$ Program Studi Agroteknologi, Fakultas Pertanian, Universitas Timor Kefamenanu \\ \Komunikasi Penulis, email : jefrianusnino@gmail.com \\ DOI:http://dx.doi.org/10.23960/jtep-lv9i4.336-342 \\ Naskah ini diterima pada 28 September 2020; revisi pada 27 November 2020; \\ disetujui untuk dipublikasikan pada 16 Desember 2020
}

\begin{abstract}
Corn is a source of carbohydrate commodity which has problems during storage. The problem that is often found is high aflatoxin contamination attacked by microorganisms and fungi. Corn has a high water content after being harvested. Aflatoxin contamination is generally caused by the high water content in corn due to the post-harvest handling process that is not fast enough after the corn is harvested. Drying is a process of diffusing water from the material into the atmosphere to reach the standard water content of storage. The weakness of this drying method is the occurrence of temperature fluctuations due to erratic weather. This condition can cause aflatoxin contamination in corn. This study aims to determine the levels of maize aflatoxin from the variable drying time using natural air. The research method includes drying testing in the field and continued with analysis of changes in water content, analysis of levels of aflalatoxin in the laboratory. Based on the results of the study, it was noted that with an initial moisture content of $25.93 \% \mathrm{bb}$, an average ambient temperature of $36.77^{\circ} \mathrm{C}$, an average humidity of $76.86 \%$ was able to reduce levels to a final moisture content of $15.12 \% \mathrm{bb}$. The results of the aflatoxin analysis of the drying time variable used did not occur aflatoxin contamination.
\end{abstract}

Keywords: aflatoxins, corn, natural air drying

\begin{abstract}
ABSTRAK
Jagung merupakan salah satu komoditas sumber karbohidrat yang mempunyai masalah pada saat penyimpanan. Masalah yang sering ditemukan yakni kontaminasi aflatoksin yang cukup tinggi. Kontaminasi aflatoksin umumnya disebabkan oleh cendawan Aspergillus flavus pada bahan dengan kadar air yang cenderung tinggi. Hal ini diakibatkan oleh proses penanganan pascapanen yang kurang cepat setelah jagung dipanen. Salah satu cara pencegahan kontaminasi aflatoksin yakni pengeringan. Pengeringan merupakan sebuah proses difusi air dari bahan ke atmosfir untuk mencapai kadar air standar penyimpanan. Kelemahan dari metode pengeringan alami yakni terjadinya fluktuasi suhu akibat cuaca yang tidak menentu. Kondisi tersebut dapat menyebabkan terjadinya kontaminasi aflatoksin pada jagung. Penelitian ini bertujuan untuk mengetahui kadar aflatoksin jagung dari variabel lama waktu pengeringan pada pengeringan menggunakan udara alamiah. Metode penelitian mencakup pengujian pengeringan di lapangan dan dilanjutkan analisis perubahan kadar air, dan analisis kadar aflalatoksin di laboratorium. Berdasarkan hasil penelitian tercatat bahwa dengan kadar air awal 25,93\% bb, suhu lingkungan rata-rata $36,77^{\circ} \mathrm{C}$, kelembaban lingkungan rata-rata $76,86 \%$ mampu menurunkan kadar hingga kadar air akhir $15,12 \%$ bb. Hasil analisis aflatoksin variabel lama pengeringan yang digunakan tidak terjadi kontaminasi aflatoksin.
\end{abstract}

Kata Kunci: aflatoksin, jagung, pengeringan udara alamiah

\section{PENDAHULUAN}

Jagung merupakan salah satu komoditas yang mempunyai masalah pada saat penanganan pascapanen. Masalah yang sering ditemukan yakni kontaminasi aflatoksin yang cukup tinggi dan penyusutan hasil. Aspergillus merupakan cendawan penghasil utama aflatoksin yang dapat mencemari bahan pangan dan pakan pada kegiatan pra dan pascapanen (Kumar et al. 2008; 
Milicevic et al. 2010; Paterson dan Lima 2010). Zat ini berbahaya bagi kesehatan manusia maupun hewan karena bersifat toksik terhadap bahan pangan.

Kontaminasi aflatoksin disebabkan oleh cendawan Aspergillus flavus akibat kandungan air dalam biji jagung yang masih tinggi. Fente et al. (2001) menyatakan aflatoksin sebagai mikotoksin dengan sifat beracun dan karsinogenik tinggi yang dihasilkan dari beberapa strain Aspergillus flavus, Aspergillus parasiticus, dan Aspergillus nomius. Kontaminasi mitotoksin tersebut terjadi pada kondisi lingkungan yang lembab (kelembaban optimal di atas $85 \%$ ) dan suhu antara $4-40^{\circ} \mathrm{C}$ (optimal $25-32^{\circ} \mathrm{C}$ ) dengan kadar air 18\% (Reddy dan Waliyar, 2008). Pencegahan kontaminasi dan serangan mikroorganisme dilakukan dengan cara bahan dikeringkan hingga mencapai kadar air standar.

Pengeringan merupakan sebuah proses difusi air dari bahan ke atmosfir untuk mencapai kadar air standar penyimpanan. Penyimpanan jagung dengan kadar air diatas 14\% dapat mempercepat berkembangnya Aspergillus flavus. Dalam proses pengeringan metode dan lama waktu pengeringan sangat menentukan keberhasilan proses pengeringan. Semakin lama waktu pengeringan maka jumlah air yang diuapkan akan semakin lebih banyak. Hal ini diperkuat oleh penyataan Taib et al (1988) dalam Histifarina et al (2004) yakni semakin lamanya proses pengeringan maka semakin besar kemampuan bahan untuk melepaskan air dari permukaannya, sehingga kadar air yang dihasilkan semakin rendah. Salah satu metode pengeringan yang digunakan yakni pengeringan dengan memanfaatkan udara alamiah. Potensi dari pengeringan alamiah yakni memanfaatkan udara lingkungan yang tersedia gratis, bersifat ramah lingkungan serta sebagai alternatif penghematan energi termal. Metode pengeringan menggunakan udara alamiah merupakan metode yang unsur-unsur pengeringan berupa suhu udara, kelembaban udara dan sirkulasi udara sepenuhnya bergantung pada kondisi alam sehingga proses pengeringan sebaiknya dilakukan pada tempat yang udaranya kering. Kelemahan dari metode pengeringan tersebut yakni terjadinya fluktuasi suhu akibat cuaca yang tidak menentu. Keadaan cuaca yang fluktuatif menyebabkan kelembaban lingkungan meningkat. Kelembaban yang tinggi dapat memicu perkembangan Aspergillus flavus untuk menghasilkan aflatoksin. Aspergillus flavus mudah berkembang di daerah beriklim panas dan lembab terutama pada kelembaban relatif $85 \%$.

Penelitian terdahulu tentang pengeringan dengan menggunakan udara lingkungan telah dilakukan oleh Nelwan et al. (2007) dengan menggabungkan sistem pengering efek rumah kaca (ERK) hybrid dengan In Store Drayer (ISD). Pada sistem ini pengeringan dilakukan pada kadar air jagung panen sekitar 23\% hingga mencapai kadar air akhir 16\%-20\% dengan menggunakan pengeringan ERK. Setelah mencapai kadar air 16\%-20\% jagung dipindahkan ke pengeringan dengan ISD. Thaariq (2013) juga melakukan penelitian pengendalian pengeringan menggunakan udara lingkungan dengan suhu rata-rata $29.15^{\circ} \mathrm{C}$ pada komuditas jagung varietas pioneer dengan kadar air awal $20 \%$ bb hingga akhirnya menjadi $13.26 \%$ bk selama 69.5 jam. Nino (2017) telah melakukan penelitian pengujian kadar aflatoksin pada pengeringan jagung mengunakan udara alamiah dengan waktu pengeringan yang lebih lama yakni 32 jam. Berdasarkan hasil penelitian nilai aflatoksin yang dihasilkan yakni jenis aflatoksin B1 (1.98 ppb), B2 (2 ppb), G1 (1.08 ppb) dan G2 (1.5 ppb). Berdasarkan hasil penelitian tersebut maka perlu kajian lebih mendalam tentang pengaruh lama pengeringan terhadap kadar aflatoksin jagung dengan metode pengeringan udara alamiah. Penelitian ini bertujuan untuk mengetahui kadar aflatoksin jagung dari variabel lama waktu pengeringan pada pengeringan menggunakan udara alamiah.

\section{BAHAN DAN METODE}

Penelitian ini dilaksanakan pada bulan April sampai September 2020. Penelitian dilakukan di Kelurahan Sasi, Kecamatan Kota Kefamenanu, Kabupaten Timor Tengah Utara, Provinsi Nusa Tenggara Timur dan dilanjutkan di di Laboratorium Fakultas Pertanian Universitas Timor dan Laboratorium Seameo Biotrop Bogor. Alat yang digunakan dalam penelitian yakni tipe 
pengering tumpukan (batch drying) (diameter $40 \mathrm{~cm}$, tinggi $80 \mathrm{~cm}$ ). Blower 1 phase dengan daya 180 watt, recorder, oven, anemometer, multimeter, tang ampere, manometer pipa U, plat orifice. Bahan yang akan digunakan adalah jagung pipilan varietas lokal kuning yang diperoleh dari Desa Manusasi, Kecamatan Miomaffo Barat, Kabupaten Timor Tengah Utara.

\subsection{Tahap Penelitian dan Set Up Pengujian} Set up pengujian pada penelitian ini terdiri dari beberapa tahap antara lain:

1.Penelitian dilakukan pada 3 unit pengering dengan ukuran masing-masing unit pengering sama (Gambar 1 ).

2.Pengujian dilakukan dengan laju aliran udara sebesar $0.020 \mathrm{~m} 3 / \mathrm{s}$ dengan variabel lama waktu pengeringan 32 jam, 24 jam dan 12 jam.

3.Lama waktu pengeringan (Skema waktu pengoperasian) dari ketiga unit pengering berbeda-beda. Pada skema (I) pengeringan berlangsung dari pukul 08:00-16:00, skema (II) pengeringan berlangsung dari pukul 09:00-15:00, dan skema (III) pengeringan berlangsung dari pukul 10:00-14:00 yang dilakukan setiap hari hingga kadar air jagung $14 \%$.

Pada Gambar 1 ditunjukkan sistem skema waktu pengoperasian (pengeringan) pada ke-3 unit pengering yang dilakukan pada waktu yang berbeda-beda. Penelitian dilakukan dua tahap yakni tahap pengujian lapangan (proses pengeringan) dan dilanjutkan tahap pengujian laboratorium (analisis aflatoksin dan kualitas). Tahapan penelitian dapat dilihat pada Gambar 2.

\subsection{Parameter Pengujian dan Analisis Data}

\subsubsection{Suhu Udara Pengering}

Pengukuran suhu udara dilakukan dengan mengukur suhu lingkungan dan suhu tumpukan jagung pipilan. Bagian-bagian pengukuran suhu adalah udara lingkungan disekitar pengeringan, dalam tumpukan jagung pipilan, dan outlet. Titik pengukuran suhu dalam tumpukan dilakukan pada 2 titik yakni bagian atas dan bagian bawah. Pengukuran dilakukan dengan menggunakan sensor TMP36 yang dikalibrasi dengan oil bath menggunakan termometer standar. Pengukuran dilakukan dengan selang waktu 30 menit.

\subsubsection{Kelembaban Relatif (RH) Udara}

Pengukur kelembaban relatif udara pengering dilakukan dengan mengukur kelembaban relatif lingkungan dan kelembaban relatif tumpukan setelah melewati tumpukan atas jagung (outlet). Pengukuran kelembaban relatif menggunakan sensor TMP36 (dikalibrasi) bola basah dan bola kering. Sensor TMP36 bola basah dibuat dengan menyelubungi ujung sensor menggunakan kain kasa dan dijaga agar tetap basah. Pengukuran dilakukan dengan selang waktu 30 menit.

\subsubsection{Kadar Air}

Pengukuran kadar air jagung pipilan dilakukan 2 tahap yakni sebelum pengeringan berlangsung atau setelah dipanen dan selama proses pengeringan berlangsung. Untuk mengetahui perubahan kadar air selama proses pengeringan maka pengukuran dilakukan dengan interval waktu 1 jam dengan menggunakan metode gravimetri (oven) pada suhu $105^{\circ} \mathrm{C}$ dengan mengeringkan sampel selama 24 jam, digunkan

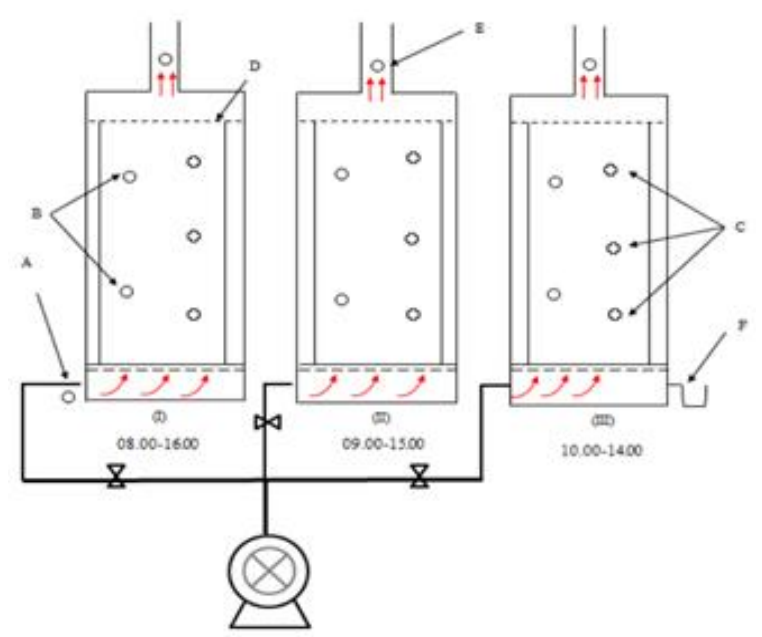

Gambar 1. Skema Waktu Pengoperasian pada Waktu Pengeringan yang Berbeda-beda 


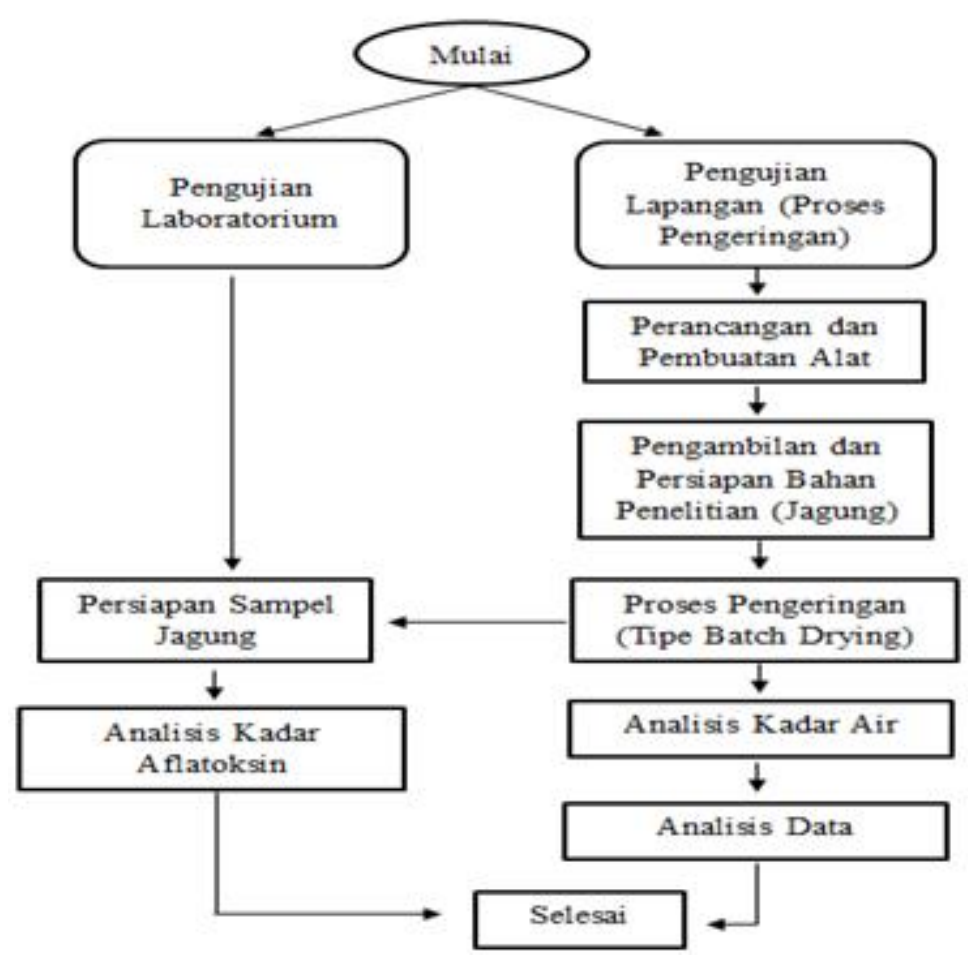

Gambar 2. Tahapan Penelitian Pengering Jagung Pipilan Tipe Tumpukan (Bed Drying) dan Analisis Kadar Aflatoksin dan Proksimat

3 sampel dengan berat masing-masing sampel 10 gram. Pengambilan sampel dilakukan pada 3 titik yakni tumpukan bagian atas, bagian tengah dan bawah. Kadar air jagung selama proses pengeringan dihitung dengan Persamaan (1):

$$
m=\frac{W m}{W m+W d} \times 100 \%
$$

dimana $m$ adalah kadar air basis basah ( $\% \mathrm{bb})$, $W m$ adalah berat air dalam bahan $(\mathrm{g}), W d$ berat bahan kering atau padatan bahan (g).

\subsubsection{Analisis Aflatoksin}

Metode yang digunakan untuk menganalisis kadar aflatoksin yakni metode HPLC (High Performance Liquid Chromatography). Analisis dilakukan di laboratorium Semeo Biotrop Bogor. Untuk analisis aflatoksin dibutuhkan sampel dengan berat 25 gram.

\section{HASIL DAN PEMBAHASAN}

\subsection{Perubahan Suhu dan Kelembaban Relatif Selama Proses Pengeringan}

Selama proses pengeringan berlangsung suhu lingkungan lebih tinggi dari pada suhu tumpukan (ruang pengering). Namun pada pukul 14:30
WITA hingga 16:00 WITA suhu lingkungan hampir sama dengan suhu tumpukan. Hal ini dikarenakan pada pagi hari suhu udara lingkunga terus meningkat hingga siang hari dan kemudian menuruan kembali pada sore hari sehingga kondisi tersebut kurang potensial sebagai media pengering. Kondisi yang sangat potensial sebagai media pengeringan yakni pada pukul 10:00 WITA hingga 14:00 WITA dengan kisaran suhu maksimum $35^{\circ} \mathrm{C}$ sampai $40^{\circ} \mathrm{C}$. Kondisi peningkatan suhu yang dimulai dari pukul 10.0014.00 WITA kemudian mengalami penurunan pada pukul 14.30 WITA ini sangat berhubungan dengan radiasi matahari yang dipancarkan ke permukaan bumi. Pada pukul 10.00-14.00 WITA radiasi yang dipancarkan matahari mendekati garis tegak lurus dengan permukaan bumi. Selama proses pengeringan berlangsung suhu lingkungan cenderung fluktuatif dikarenakan fluktuasi cuaca. Suhu lingkungan rata-rata $36.77^{\circ} \mathrm{C}$, suhu tertinggi selama proses pengeringan berlangsung sebesar $40.84^{\circ} \mathrm{C}$ sedangkan suhu terendah sebesar $28.53^{\circ} \mathrm{C}$. Gambar 3 memperlihatkan grafik fluktuasi suhu lingkungan dengan suhu tumpukan terhadap bertambahnya waktu selama pengeringan. 
Berdasarkan hasil penelitian terlihat bahwa perbedaan kelembaban relatif lingkungan dan kelembaban relatif outlet sangat signifikan, dimana kelembaban relatif lingkungan lebih rendah dari pada kelembaban relatif outlet. Ratarata kelembaban relatif lingkungan sebesar $70 \%$ sedangkan rata-rata kelembaban relatif outlet sebesar $85 \%$. Semakin rendah suhu udara lingkungan kelembaban relatif yang dihasilkan semakin besar sehingga lebih sedikit uap air yang diserap oleh udara pengering. Semakin rendah kelembaban relatif udara pengering maka proses perpindahan panas dan massa dari bahan ke udara makin besar (Agusniar dan Setiyani. 2011).

\subsection{Perubahan Kadar Air Selama Proses Pengeringan}

Kadar air awal jagung yang digunakan pada penelitian tersebut yakni $25.93 \%$ bb. Berdasarkan grafik terlihat bahwa dengan suhu lingkungan rata-rata $36.77^{\circ} \mathrm{C}$, dan kelembaban lingkungan rata-rata 70\% mampu menurunkan kadar air hingga kadar air akhir $12.30 \%$ bb. Secara berurutan kadar air akhir perlakuan lama pengeringan 32 jam, 24 jam dan 12 jam yakni $12,58 \%$ bb, $15.32 \%$ bb dan $17.46 \%$ bb. Semakin tinggi suhu udara dan lama waktu pengeringan maka peluang air yang diuapkan dari bahan akan semakin lebih banyak. Menurut Fitriana (2008) bahwa kemampuan bahan untuk melepaskan air dari permukaannya akan semakin besar dengan meningkatnya suhu udara pengering yang digunakan, sehingga kadar air yang dihasilkan semakin rendah. Gambar 5 memperlihatkan grafik perubahan kadar air selama proses pengeringan pada ketiga perlakuan lama pengeringan.

Selama proses penelitian penurunan kadar air pada lapisan bawah selalu lebih rendah untuk keseluruhan perlakuan lama pengeringan. Hal ini dikarenakan pada lapisan bawah memiliki ketebalan tumpukan lebih dekat dengan suhu inlet sehingga lebih cepat terjadi penguapan uap air dari bahan yang mengakibatkan penurunan kadar air lebih cepat. Semakin tipis atau kecil lapisan jagung maka semakin cepat dan besar penurunan kadar air biji jagung per satuan waktu (Bintoro et al. 2012). Pada lapisan bagian tengah dan atas penurunan kadar air sangat lambat. Hal ini dikarenakan semakin tebal lapisan jagung kemungkinan distribusi panas udara pengering

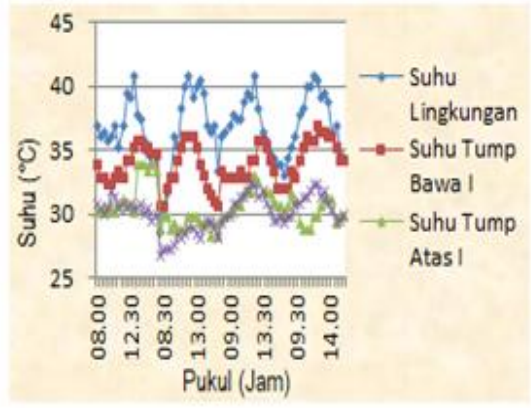

a

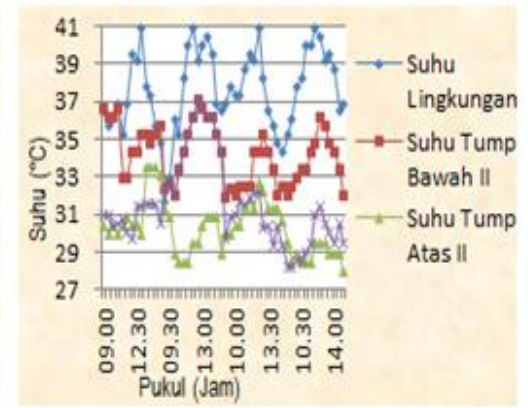

$\mathrm{b}$

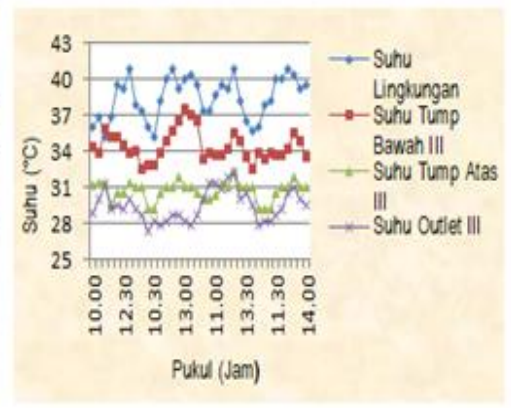

C

Gambar 3. Perubahan(a) Suhu Lingkungan, (b) Suhu Tumpukan, dan (c) Suhu Outlet Selama Proses Pengeringan

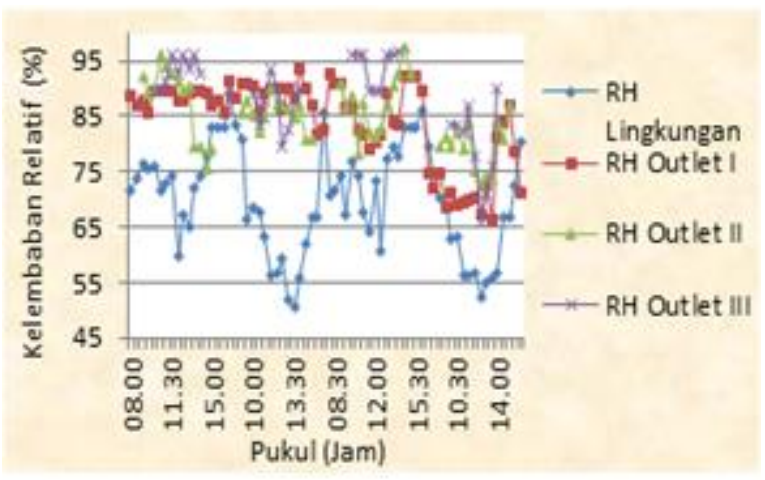

Gambar 4. Perubahan Kelembaban Relatif Selama Proses Pengeringan 


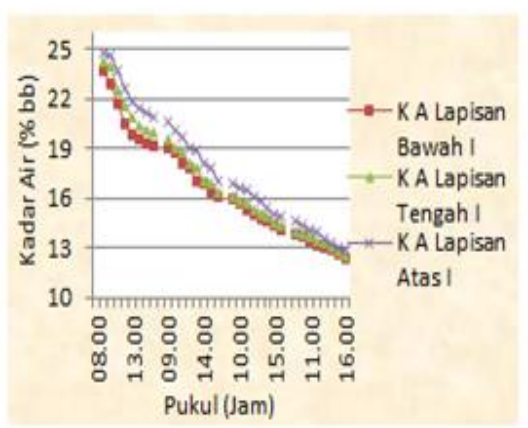

$\mathrm{a}$

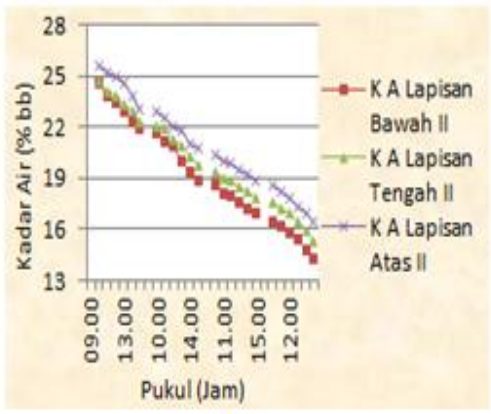

b

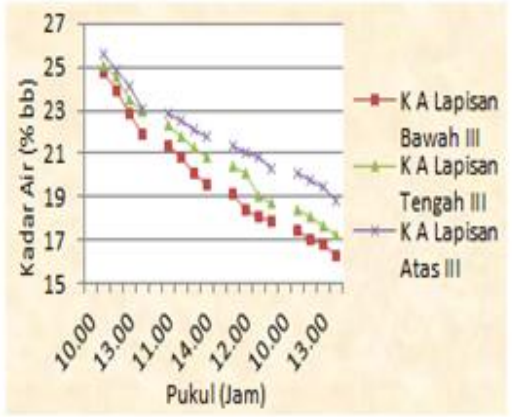

C

Gambar 5. Perubahan Kadar Air Selama Proses Pengeringan: (a) Pengering I, (b) Pengering II, dan (c) Pengering III

Tabel 1. Hasil Analisis Kadar Aflatoksin Lama Pengeringan 32 jam, 24 jam dan 12 jam.

\begin{tabular}{ccccc}
\hline & & \multicolumn{3}{c}{ Hasil Uji Laboratorium Kadar Aflatoksin $(\boldsymbol{\mu g} / \mathbf{k g})$} \\
\cline { 3 - 5 } No. & Jenis Aflatoksin & $\begin{array}{c}\text { Lama Pengeringan } \\
\text { 32 Jam }\end{array}$ & $\begin{array}{c}\text { Lama Pengeringan } \\
\text { 24 Jam }\end{array}$ & $\begin{array}{c}\text { Lama Pengeringan } \\
\text { 12 Jam }\end{array}$ \\
\hline 1 & B1 & $<0.28$ & $<0.28$ & $<0.28$ \\
2 & B2 & $<2.02$ & $<2.02$ & $<2.02$ \\
3 & G1 & $<1.53$ & $<1.53$ & $<1.53$ \\
4 & G2 & $<0.20$ & $<0.20$ & $<0.20$ \\
\hline
\end{tabular}

Sumber : Seameo Biotrop Services Laboratory, 2020

semakin terhambat oleh kepadatan biji jagung sehingga penurunan kadar air menjadi lambat.

\subsection{Analisis Kadar Aflatoksin}

Sistem pertanian di daerah yang beriklim tropis memiliki suhu yang relatif tinggi dan umumnya menghasilkan komoditas pangan yang rentan terhadap jamur penghasil aflatoksin. Secara geografis keadaan daerah Timor beriklim tropika kering dengan suhu udara tertinggi diawal musim kemarau sebesar $34.65^{\circ} \mathrm{C}$ dan kelembaban relatif lingkungan sebesar 73.16\%, (Nino, 2017). Berdasarkan keadaan iklim tersebut kelembaban relatif lingkungan cukup tinggi sebagai media pemicu perkembangan Aspergillus flavus untuk memproduksi aflatoksin. Tabel 1 menunjukkan kadar aflatoksin jagung pada lama pengeringan 32 jam, 24 jam dan 12 jam. Berdasarkan hasil analisis, nilai kadar aflatoksin yang dihasilkan dari ketiga perlakuan lama pengeringan sangat memenuhi sebagai bahan pangan maupun pakan dikarenakan nilai kadar aflatoksin yang dihasilkan jauh lebih kecil dari nilai kadar aflatoksin yang dipersyaratkan oleh SNI jagung untuk pangan maupun pakan sebesar 100,0 $\mu \mathrm{g} /$ $\mathrm{kg}$.
Berdasarkan Tabel 1, terlihat bahwa nilai kadar aflatoksin yang dihasilkan dari variabel lama pengeringan 32 jam (pengeringan lebih lama) memiliki nilai kadar aflatoksin sama dengan lama pengeringan 12 jam. Hal ini dapat katakan bahwa udara alamiah di daerah Timor sangat berpotensi sebagai media pengering dalam mencegah kontaminasi aflatoksin. Kondisi tersebut didasarkan dari hasil pengukuran kelembaban relatif lingkungan selama proses pengeringan sebesar $76.86 \%$ dan kadar air akhir rata-rata $15.12 \%$ bb. Pada bahan pangan perkembangan Aspergillus flavus akan mudah berkembang pada kelembaban relatif lingkungan minimum $80 \%$. Hal ini didukung dengan pernyataan (Reddy \& Waliyar, 2008) yakni produksi mitotoksin terjadi pada kondisi lingkungan dengan kelembaban relatif diatas 80\%. Menurut Yunus et al. (2011) faktor utama dalam pembentukan aflatoksin yang dihasilkan oleh kapang Aspergillus flavus adalah kelembaban relatif (RH) minimum sebesar $80 \%$. Dengan demikian metode pengeringan dengan variabel lama pengeringan 32 jam, 24 jam dan 12 jama menggunakan udarah alamiah sangat direkomendasikan sebagai salah satu metode pengeringan untuk bahan pangan maupun pakan. 


\section{KESIMPULAN}

Berdasarkan hasil penelitian dapat disimpulkan bahwa dengan kadar air awal $25.93 \%$ bb, suhu lingkungan rata-rata $36.77^{\circ} \mathrm{C}$, kelembaban lingkungan rata-rata 70\% mampu menurunkan kadar hingga kadar air akhir $15.12 \%$ bb. Hasil analisis aflatoksin menunjukkan bahwa tidak terjadi kontaminasi aflatoksin. Nilai kadar aflatoksin yang dihasilkan sangat kecil dari nilai standar aflatoksin SNI. Nilai kadar aflatoksin yang dihasil ketiga variabel lama pengeringan yakni B1 $(<0.28 \mu \mathrm{g} / \mathrm{kg}), \mathrm{B} 2(<2.02 \mu \mathrm{g} / \mathrm{kg}) \mathrm{G} 1$ $(<1.53 \mu \mathrm{g} / \mathrm{kg}) \mathrm{G} 2(<0.20 \mu \mathrm{g} / \mathrm{kg})$.

\section{UCAPAN TERIMA KASIH}

Peneliti mengucapkan limpahan terimakasih yang tidak terhingga kepada Direktorat Jenderal Pendidikan Tinggi, Kementerian Pendidikan dan Kebudayaan Republik Indonesia yang telah memberikan dana Hibah Penelitian Dosen Pemula dengan Nomor Kontrak : 075/SP2H/ AMD/LT/DRP/2020 sehingga peneliti dapat menyelesaikan penelitian dengan baik.

\section{DAFTAR PUSTAKA}

Agusniar, A. dan Setiyani, D. 2011. Pengeringan jagung dengan metode mixed adsorpstion drying menggunakan zeolite pada unggun terfluidisasi. Jurnal Teknologi Kimia dan Industri 2(2): 103-110 .

Bintoro, N., Nugroho, J., Maria, D. 2012. Pengembangan metode dan peralatan pengering mekanis untuk biji-bijian dalam karung. Prosiding Seminar Nasional Perteta, 30 November - 2 Desember 2012. Malang, Indonesia: 278-285.

Fente, C. A., Jaimez, O.J., Vazquez, B. I., Franco, C.M., Cepeda, A. 2001. New additive for culture media for rapid identification of aflatoxin-producing Aspergillus strain.
Applied and Environmental Microbiology 67(10): 4858-4862.

Histifarina, D., Musaddaad, D., Murtiningsih, E. 2004. Teknik pengeringan dalam oven untuk irisan wortel kering bermutu. Jurnal Hortikultura 14(2): 107-112.

Kumar, V., Basu, M. S., Rajendran, T. P. 2008. Mycotoxin research and mycroflora in some commercially important agricultural commodities. Crop Protection 27: 891905

Milicevic, D., Skrinjar, S., Baltic, T. 2010. Real and perceived risks for mycotoxin contamination in foods and feeds : Challenges for food safety control. Toxins 2(4): 572-592.

Nelwan, L.O., Wulandani, D., Paramawati, R., Widodo, T. W., Mulyantara, F.X.L.T., Hendarto, D., Nurba, D. 2007. Rancang bangun alat pengering efek rumah kaca (ERK) hybrid dan in store dryer terintegrasi untuk biji-bijian. Laporan Proyek Penenlitian KKP3T Dapartemen Pertanian. Nelwan, Leopold Oscar

Nino, J. 2017. Aplikasi Pengeringan Udara Alamiah Untuk Jagung Pipilan Di Daerah Timor. Thesis. Institut Pertanian Bogor.

Paterson, R. R. M., dan Lima, N. 2010. How will climate change affect mycotoxin in food. Food Research International 43: 19021914.

Reddy, S. V., dan Waliyar, F. 2008. Properties of Aflatoxin and Its Producing Fungi. http:// www.aflatoxin.info/aflatoxin.asp. [30 Januari 2013]. 